\title{
EFEK TERAPI MUSIK \& DEEP BREATHING EXERCISE TERHADAP PENURUNAN NYERI, FREKUENSI NADI, FREKUENSI PERNAPASAN PADA PASIEN KANKER PARU
}

\author{
Aprillia Veranita $^{1^{*}}$, Ni Luh Widani ${ }^{2}$, Wilhelmus Hary Susilo ${ }^{3}$ \\ 1. Keilmuan Keperawatan Medikal Bedah, STIK Sint Carolus, Jakarta-Indonesia \\ 2. Keilmuan Keperawatan Medikal Bedah, STIK Sint Carolus, Jakarta-Indonesia \\ 3. Keilmuan Keperawatan Medikal Bedah, STIK Sint Carolus, Jakarta-Indonesia \\ *Korespondensi: Aprilia Veranita | STIK Sint Carolus | aprilliaveranita@gmail.com
}

\begin{abstract}
Abstrak
Pendahuluan: Kanker paru adalah pertumbuhan sel yang tidak terkendali pada paru-paru yang sering menimbulkan nyeri dan sesak napas. Manajemen nyeri yang tepat diperlukan untuk menangani respon nyeri. Penelitian ini bertujuan untuk mengetahui pengaruh terapi musik \& Deep Breathing Exercise (DBE) terhadap penurunan nyeri, frekuensi nadi dan pernapasan pada pasien kanker paru.

Metode: Penelitian ini merupakan studi quasi experimental pre-post test with control group dengan teknik purposive sampling ,terdiri dari 86 responden kelompok intervensi dan 22 kelompok kontrol di RSUP Persahabatan. Nyeri diukur dengan Numeric Rating Scale (NRS). Analisis yang digunakan adalah Uji regresi linear berganda, Paired sampel t-test, Independent t-test.

Hasil: Hasil penelitian menunjukan perbedaan bermakna nilai skala nyeri, frekuensi pernapasan dan nadi sebelum dan sesudah intervensi terapi musik dan Deep Breathing Exercise (DBE) $(\mathrm{p}=0,000)$.

Kesimpulan: Penurunan skala nyeri, frekuensi pernapasan dan nadi kelompok intervensi lebih besar dari pada kelompok kontrol. Penelitian ini merekomendasikan terapi musik \& DBE sebagai intervensi mandiri keperawatan untuk mengurangi nyeri kanker paru.
\end{abstract}

Kata Kunci : Deep Breathing Exercise, Kanker paru, Terapi musik.

Diterima 17 Oktober 2018; Accepted 30 Desember 2018

\section{PENDAHULUAN}

Penyakit berdasarkan jenis nya dapat dibedakan menjadi penyakit infeksi dana noninfeksi. Penyakit non infeksi adalah penyakit yang disebabkan selain dari proses infeksi, seperti penyakit kanker, jantung dan pembuluh darah, serta diabetes mellitus, Kanker paru, kanker hati, kanker perut, kanker kolorektal, dan kanker payudara merupakan jenis penyakit kanker tertinggi yang sering diderita manusia setiap tahunnya. Pada dasarnya penyakit ini dapat dicegah. Pencegahan dapat dilakukan salah satunya dengan cara mengubah perilaku. Beberapa contoh pola perilaku berisiko adalah pola makan dan gaya hidup (life style) yang tidak sehat, seperti merokok, mengkonsumsi alkohol,dan mengkonsumsi makanan siap saji (fast food).

Merokok merupakan risiko tinggi penyebab terjadinya kanker paru. Dari data World Health Statistic WHO tahun 2014 prevalensi merokok dewasa usia $\geq 15$ tahun di tahun 2011 sebanyak 67\% pada laki-laki dan 3\% pada perempuan. Selanjutnya, dari data World Health Statistic WHO tahun 2015 prevalensi merokok pada usia dewasa $\geq 15$ tahun mengalami peningkatan pada tahun 2012, yaitu sebanyak 71,8\% pada pria dan $4 \%$ pada perempuan. Gambaran jumlah perokok di Indonesia yang merokok setiap harisejak tahun 2007-2013 terus mengalami peningkatan dari 23,7\% menjadi 24,3\% (Riskesdas, 2007 dan Riskesdas, 2013).

Sebagian kanker paru-paru tidak menimbulkan gejala sampai kanker tersebut telah menyebar. Gejala umum dari kanker paru adalah batuk yang terus-menerus, batuk berdarah, mengi, berat badan turun, sesak napas, dan nyeri dada (Gentara, 2015). Diagnostik pasti stadium kanker paru dapat diketahui melalui sistem stadium TNM (tumor-node-metastasis). Nyeri dapat berasal dari penyakit kanker atau dari dampak pengobatan, seperti kemoterapi, radiasi, dan pembedahan (Kaliyaperumal, 2010). Salah satu terapi komplementer yang dapat digunakan untuk menurunkan nyeri adalah terapi musik. Musik diketahui memiliki banyak sekali manfaat, antara lain, untuk relaksasi otot, mengurangi nyeri, memperlambat denyut jantung, meningkatkan kedalaman pernapasan, serta mengurangi kecemasan dan depresi (Jasemi, 2013).

Kesulitan bernapas juga dialami oleh pasien kanker paru. Teknik pernapasan yang baik dapat 
membantu mengatasi nyeri dada pasien. Penggunaan terapi komplementer dapat dilakukan pada pasien nyeri dada. Deep Breathing Exercise merupakan latihan mengatur pernapasan agar pernapasan menjadi lebih baik.Dasar pemilihan intervensi terapi musik adalah musik diketahui memiliki banyak sekali manfaat, antara lain, untuk relaksasi otot, mengurangi nyeri, memperlambat denyut jantung, meningkatkan kedalaman pernapasan, serta mengurangi kecemasan dan depresi serta musik sudah lama dikenal dikalangan masyarakat umum, mudah di dapatkan dan biayanya murah. Sedangkan Deep Breathing Exercise merupakan latihan pernapasan yang dapat dilakukan oleh pasien secara mandiri, tidak memerlukan ruangan yang besar, namun dapat dilakukan pada saat pasien sedang duduk atau di tempat tidur.

Penderita kanker paru yang berobat ke RSUP Persahabatan di Jakarta Timur berjumlah 265 orang per Oktober-Desember 2015. Kondisi pasien yang mendatangi rumah sakit pada umumnya sudah mencapai stadium lanjut, sebanyak 25\% pasien kanker perempuan dan $75 \%$ pasien kanker pria. Kondisi pasien pada umumnya mengalami nyeri serta gangguan oksigenasi yang membutuhkan bantuan orang lain. Tindakan keperawatan yang dilakukan oleh perawat dalam mengatasi kondisi tersebut adalah dengan memberikan intervensi berupa terapi medis.

\section{METODE}

Peneliti menggunakan desain quasi experimental pre-post test with control group dengan teknik purposive sampling, dengan jumlah sampel 108 orang yangterdiri dari masing-masing 86 kelompok intervensi dan 22 kelompok kontrol. Adapun sampel yang dipilih memenuhi krteria inklusi dan eksklusi antara lain, bersedia menjadi responden, bersedia tidak mendengarkan musik lain selama 3 hari, kesadaran kompos mentis , umur $\geq 20$ tahun, pasien menderita kanker paru yang dirawat dengan nyeri kronis (skala nyeri 4-6), pasien menderita kanker paru yang dirawat dengan perbaikan keadaan umum, pasien sedang di rawat inap di RSUP Persahabatan Jakarta. Kriteria ekslusi pada polpulasi sumber/sample frame ialah sebagai berikut: mengalami gangguan pendengaran, tidak bersedia diteliti, pasien dalam kondisi akut seperti sesak berat, sianosis, dan gelisah. Waktu pengumpulan data Oktober-Desember 2015, Penelitian ini memegang tujuh prinsip etik yaitu Prinsip Self Determinan, Privacy, Anonymity atau Confidentiality, Protection Discomfort, Beneficience, Justice, Informed Consent .

Sebelum dilakukan perlakuan, kelompok intervensi dan kelompok kontrol dilakukan pengukuran skala nyeri, frekuensi nadi dan pernapasan. Pada kelompok intervensi mendapat 2 perlakuan yaitu terapi musik dan Deep Breathing Exercise. Intervensi terapi musik diberikan selama tiga hari berturut-turut dengan durasi 20 menit, setelah selesai terapi musik pasien diistirahatkan selama 5 menit kemudian dilakukan pengukuran skala nyeri, frekuensi nadi post intervensi. Intervensi DBE diberikan 2 jam setelah terapi musik dilakukan sebanyak 4 siklus selama 5 menit, sebelum dan setelah intervensi dilakukan pengukuran frekuensi pernapasan post intervensi .Prosedur pengumpulan data responden, format data kelompok intervensi terapi musik, format kelompok intervensi Deep Breathing Exercise, Pengumplan data kelompok kontrol, Numeric Rating Scale (NRS).

Penentuan sampel penelitian yang menderita penyakit kanker paru ditentukan dengan cara melihat dokumentasi status pasien pada lembar diagnosis, hasil pemeriksaan diagnostik khususnya Torak foto, CT Scan dan Bronkoskopi, pemeriksaan laboratorium Hemoglobin (apabila pasien masuk dengan Hb rendah), serta tanda-tanda vital yaitu frekuensi nadi dan frekuensi pernapasan. Setelah teridentifikasi sebagai pasien kanker paru, peneliti mencocokan sesuai dengan kriteria inklusi yang telah ditetapkan dalam penelitian. Peneliti menjelaskan tujuan penelitian, manfaat, serta prosedur penelitian. Peneliti meminta pasien menandatangani lembar informed consent bagi pasien yang bersedia menjadi responden. Melakukan pengkajian karakteristik responden kelompok intervensi. Peneliti menjelaskan tentang cara pengisian kuesioner karakteristik responden dan instrument pengkajian skala nyeri (NRS).

Responden diminta untuk menunjukan tingkat nyerinya pada skala 0-10 yang ada pada instrumen pengkajian Numeric Rating Scale untuk menilai skala nyeri pasien. Responden diberi waktu selama 5 menit untuk menepatkan diri pada posisi yang nyaman menurut responden, responden mulai mendengarkan instrument musik dengan menggunakan headphone. Peneliti berada menjaga jarak dengan pasien untuk mencegah distraksi tetapi masih dalam jangkaun pasien untuk terus dapat memonitor keadaan pasien.

Terapi musik berlangsung selama 20 menit (dihitung dengan menggunakan stopwatch, yang dimulai 
sejak tombol play ditekan). Setelah 20 menit, musik dihentikan dan headphone dilepaskan. Responden diminta untuk istirahat sejenak, setelah 5 menit dilakukan pengukuran frekuensi nadi post intervensi. Pengkajian nyeri dilakukan pada periode 10 menit sejak tombol off pada MP3 ditekan. engkajian skala nyeri dengan menggunakan NRS sesudah intervensi. Intervensi dilakukan pada hari berikutnya pada waktu yang sama.

\section{HASIL}

Hasil analisis univariat karakteristik responden berdasarkan umur RSUP Persahabatan , rerata umur pada kelompok intervensi dan kelompok kontrol adalah 20-50 tahun (54\%) berada pada rentang, laki-laki (73\%), Mantan perokok $(67,25 \%)$, stadium kanker $4(78,74 \%)$. Rata-rata skala nyeri pre $(5,03)$ dan post $(4,09)$ berada pada skala sedang, frekuensi nadi pre $(91,83)$ dan post $(83,62)$ berada pada batas normal, frekuensi pernapasan pre $(22,65)$ dan post $(20,45)$ berada diatas normal.

\section{Hasil analisis Uji paired sample t-test}

Perbedaan skala nyeri, frekuensi nadi, frekuensi pernapasan sebelum dan sesudah intervensi dengan (nilai $\mathrm{p}=0,000$ ).

\section{Hasil analisis Uji Beda Independen t-test}

Secara statistik terdapat perbedaan yang signifikan pada skala nyeri $(\mathrm{p}=0,034)$, frekuensi nadi $(\mathrm{p}=0,546)$, frekuensi pernapasan $(\mathrm{p}=0,047)$ antara kelompok intervensi Terapi Musik dan DBE dengan kelompok kontrol.

\section{Hasil analisis Regresi Linear Berganda}

Intervensi terapi musik dan DBE, umur, jenis kelamin, stadium kanker, secara simultan berpengaruh terhadap perubahan skala nyeri, frekuensi pernapasan, frekuensi nadi $(\mathrm{p}=0,000)$.

\section{PEMBAHASAN}

Penelitian menilai karakteristik responden berdasarkan umur ,mayoritas umur 20-50 tahun (54 \%) berada pada rentang, laki-laki (73\%), Mantan perokok (67,25\%), stadium kanker 4 (78,74\%). Hasil penelitian ini sesuai dengan teori yang ditulis oleh (Potter, 2006; Sharewood, 2009) mengatakan umur merupakan variabel paling penting yang mempengaruhi nyeri, terutama pada anak dan lansia . Perbedaan perkembangan, yang ditemukan antara kelompok umur ini dapat mempengaruhi bagaimana anak, orang dewasa dan lansia bereaksi terhadap nyeri. Semakin tinggi usia seseorang, ia akan cenderung mengabaikan nyeri dan menahan nyeri karena sudah teradaptasi dengan nyeri. Hasil penelitian ini sesuai dengan hasil penelitian yang dilakukan oleh (Rao , 2004) mengatakan, sebanyak 50-90\% nyeri yang berhubungan dengan kanker dialami oleh pasien usia lanjut dan sekitar 60-70\% pasien memperoleh pengobatan untuk tumor mereka . Nyeri terkait umur telah dipelajari dan tidak ada bukti terjadinya perubahan pada tulang belakang manusia atau reseptor penuaan. Manajemen dalam pengelolaan nyeri sangat baik digunakan pada pasien kanker usia lanjut yang lemah . Terapi pijat, refleksi kaki, terapi musik, dan meditasi semuanya termasuk manajemen nyeri. Rehabilitasi dengan latihan dan terapi fisik juga dapat membantu mengurangi nyeri.

Hasil penelitian ini sesuai dengan hasil penelitian yang dilakukan oleh (Chen, 2014) mengatakan insiden kanker paru-paru terjadi pada umur kurang dari 45 tahun dan meningkat secara dramatis, pada umur 80-84 tahun atau di atas 85 tahun. Hasil penelitian ini didukung oleh hasil penelitian yang dilakukan oleh ( Hemminki, 2016) mengatakan metastasis semakin meningkat pada umur 85-89 tahun. Metastasis kanker terjadi , tergantung pada lokasi metastasis tersebut.

Pada penelitian ini, umur termuda responden adalah 20 tahun. Hasil penelitian serupa dengan yang dilakukan oleh ( Khan, 2010) mengatakan bahwa metastatik NSCLC jarang terjadi pada pasien di bawah umur 25 tahun. Yang harus dipertimbangkan adanya keganasan tambahan dengan melihat massa pada dada, pada kelompok umur ini termasuk dalam kelompok tumor germ cell, limfoma, karsinoid, dan metastasis dari kanker primer non-paru.

Hasil penelitian ini sesuai dengan hasil penelitian yang dilakukan oleh (Behera, 2012) mengatakan bahwa sebanyak $89 \%$ kanker paru terjadi pada laki-laki dan sebanyak 33\% terjadi pada perempuan yang 
pernah merokok.Prevalensi perokok di Indonesia yang merokok setiap hari sejak tahun 2007-2013 terus mengalami peningkatan dari 23,7\% menjadi 24,3\% (Riskesdas, 2007 dan Riskesdas, 2013). Peningkatan jumlah perokok akan meningkatkan jumlah individu yang berisiko mengalami kanker paru. Prevalensi kejadian kanker paru di Indonesia pada laki-laki, yaitu sebesar 34,2\%, sedangkan kematian akibat kanker paru pada laki-laki sebesar $30,0 \%$.

Hasil penelitian sesuai dengan hasil penelitian yang dilakukan oleh (Thomas, 2014) mengatakan lebih dari 70\% pasien yang didiagnosis kanker paru berada pada stadium IV yang tidak melakukan terapi kuratif. Pernyataan ini didukung oleh hasil penelitian yang dilakukan oleh (Tiwari, 2015) mengatakan bahwa pasien kanker paru yang datang ke rumah sakit dengan stadium IV. Sebagian besar alasan mengapa pasien terlambat untuk berobat, seperti ketidaksadaran pasien mengenai tanda-tanda dan gejala kanker, konsultasi dengan praktisi setempat tidak memenuhi syarat / tidak ada konsultasi, penggunaan obat-obatan alternatif, kondisi sosial-ekonomi yang buruk dan kurang tepatnya rujukan infrastruktur.

Penyebab lain tertundanya pengobatan yaitu ada kaitannya antara pasien dan sistem terkait. Sangat penting untuk memberi pendidikan secara umum pada orang awam tentang tanda-tanda awal dan gejala kanker. Pada saat yang sama, sistem perlu diperbaiki efisiensinya sehingga keterlambatan pengobatana sekunder serta hasil yang merugikan dapat dihindari.Rata-rata skala nyeri pre dan post berada pada skala sedang, frekuensi nadi pre dan post berada pada batas normal, frekuensi pernapasan pre dan post berada diatas normal.

Hasil penelitian ini sesuai dengan hasil penelitian yang dilakukan oleh (Gutgsell et al., 2013) mengatakan, perbedaan antara kelompok intervensi dengan kelompok kontrol menunjukkan penurunan nyeri yang signifikan dari pre ke post. Perubahan terbesar terdapat pada kelompok intervensi terapi musik dengan nilai $(\mathrm{p}<0,0001)$. Perbedaan skala nyeri, frekuensi nadi, frekuensi pernapasan sebelum dan sesudah intervensi dengan (nilai $\mathrm{p}=0,000$ ).

Hasil penelitian ini sesuai dengan hasil penelitian yang dilakukan oleh (Genc, Ikiz, Güneri, Izmir, 2008) dikatakan bahwa DBE meningkatkan oksigenasi setelah operasi kepala dan operasi leher, tanpa menyebabkan hemodinamik meningkat DBE menurunkan RR dari 24,1x/mnt menjadi 21.8x/menit $(\mathrm{P}=0,05)$. Hasil penelitian lain yang yang sesuai dengan penelitian ini ,dilakukan oleh (Jasemi, 2013) mengatakan intensitas nyeri pada kelompok intervensi selama 3 hari, menunjukkan penurunan yang signifikan $(\mathrm{p}<0,001)$, tetapi dalam kelompok kontrol intensitas nyeri tidak berubah selama studi $(\mathrm{p}=0,12)$.

Berdasarkan hasil penelitian pada (tabel 1) Intervensi terapi musik dan DBE, umur, jenis kelamin, stadium kanker, secara simultan berpengaruh terhadap perubahan skala nyeri, frekuensi pernapasan, frekuensi nadi. Hasil penelitian ini sesuai dengan opini dan issu terkini yang dikemukakan oleh (Musclow et al, 2002 dalam Demir , 2012) mengatakan bahwa musik dapat mengurangi nyeri juga menurunkan denyut nadi, tekanan darah, suhu tubuh, meningkatkan respirasi serta respon fisiologis lainnya, serta sebagai distraksi bagi pasien. Musik juga dapat mengurangi mual saat kemoterapi, sehingga kualitas hidup pasien kanker terminal, menjadi meningkat. Mendengarkan musik merangsang gelombang otak alpha yang dirilis untuk stimulator endorfin, sehingga menciptakan keadaan relaksasi

Pernyataan ini didukung oleh penelitian yang dilakukan oleh (Warth et al, 2014) mengatakan bahwa musik jenis monochord berhubungan dengan peningkatan aktivitas posterior theta dan penurunan alpha band pada pertengahan frontal aktivitas beta-2 band menimbulkan relaksasi. Pernyataan ini di dukung oleh penelitian lain yang dilakukan oleh (Bradt,2014) mengatakan terapi musik sangat efektif dalam menurunkan kecemasan, mengurangi nyeri, mood, dan untuk relaksasi $(\mathrm{P}=0,0001)$.

\section{KESIMPULAN}

Hasil Uji regresi linier berganda . Empat variabel independen yaitu intervensi terapi musik dan DBE, umur, jenis kelamin, stadium kanker, secara simultan berpengaruh terhadap perubahan skala nyeri, frekuensi pernapasan dan frekuensi nadi, dianjurkan agar terapi musik dan DBE dapat menjadi salah satu intervensi mandiri keperawatan.

\section{UCAPAN TERIMA KASIH}

Ucapan terima kasih kepada RS Persahabatan Jakarta ,yang telah memberi kesempatan kepada peneliti untuk melakukan peneitian, kepada dr.Elisna Syahruddin PhD.,SpP dan dr.Jamal Zaini PhD.,SpP, selaku pembimbing penelitian di lapangan, kepada Ni Luh Widani, MKep, Ners., Sp.KepMB dan 
Dr.Ir.Wilhelmus Hary Susilo, MM.,IAI.,IMARC selaku dosen pembimbing penelitian.

\section{REFERENSI}

Bahera, D (2012). Epidemiology of lung cancer-Global and Indian petspective. JIACM ; 13(2b): 131-7

Chen, Wanging, Zheng, Rongsho, Zeng, Hongmei \& Swei (2014). The Epidemiology of Lung Cance in China. J Cancer Bio Res 2 (1) :1043

Hemminki, Kari, Pavildis, Nicholas, Konstantinos K, et al (2016). Age Dependent Metastatic Spread and Survival: Cancer of Unknow Primary as a Model. Sci. Rep.6, 23725 ; doi: 10.1038/srep23725 (2016).

KemenKesRI. (2015). Profil Kesehatan Indonesia tahun 2014. Jakarta: Kementrian Kesehatan RI

Khan et al (2010). Metastatic Lung adenocarcinoma in a 20-year-old patient . Current Oncology Volume 17, Number 1

Jasemi, M. a. (2013). Music Therapy Reduces the Intensity of Pain Among Patient With Cancer.

Kozier, Erb, Berman, \& Snyder. (2010). Buku Ajar Fundamental Keperawatan; Konsep,Proses, \& Praktis. Ed 7 Vol.2. Jakarta: EGC

Kruijsen, J. M. (2013). Journal Effect of Exercise on Immune Function In Patients With Cancer: a Systematic Review.

Potter,P.A.,\& Perry,A.G (2005). Nuku ajar fundamental keperawatan: Konsep, proses, dan Pratik (Edisi 4, Vol.1).(Yasmin, dkk., Alih Bahasa). Jakarta: Penerbit Buku Kedoteran EGC

POI. (2010). Basic Science Of Oncology, Ilmu Onkologi Dasar. Jakarta: FKUI.

Mattei TA, Rodriguez AH (2013). Music therapy as an adjuvant therapeutic tool in medical practice: an evidance-based summary, OA Evidence-Based Medicine ,London : OA

Riskesdas. (2013). Jakarta: Badan Penelitian dan Pengembangan Kesehatan Kementrian Kesehatan RI.

Riskesdas. (2007). Jakarta: Badan Penelitian dan Pengembangan Kesehatan Kementrian Kesehatan RI.

Strong, J. U. (2002). Pain; A Textbook for Therapists, Issue 1. Edinburg : Churchill Livingstone.

Sharewood, Lauralee (2011), Fisiologi manusia:dari sel ke sistem (Edisi 6). (dr.Brahm U.Pendit.,Alih Bahasa). Jakarta: Penerbit Buku Kedoktera n EGC 